\title{
CRITICAL REMARKS ON EDUCATIONAL PHILOSOPHY OF PAULO FREIRE
}

\author{
M. Agus Nuryatno \\ Faculty of Tarbiyah and Teaching UIN Sunan Kalijaga Yogyakarta \\ (e-mail: agusnuryatno@yahoo.com; HP. 081804328865)
}

\begin{abstract}
Abstrak: Telaah Kritis terhadap Filsafat Pendidikan Paulo Freire. Artikel ini membahas filsafat pendidikan Paulo Freire berbasiskan riset kepustakaan. Pembahasan dibagi ke dalam tiga bagian: (a) filsafat tentang manusia; (b) arkeologi kesadaran manusia; dan (c) politik pendidikan. Filsafat manusia Paulo Freire dapat dikategorikan sebagai humanisme Marxis-Kristen, karena berbasiskan pada gagasan-gagasan yang berkembang dalam diskursus Marxis dan Kristen. Arkeologi kesadaran manusia yang dikonseptualisasi Freire merupakan sebuah studi tentang bentuk fundamental kesadaran manusia, dan bentuk-bentuk ini dapat dilihat melalui cara manusia memahami dan menerima realitas eksistensial yang melingkupinya, yaitu apakah mereka melihatnya secara magis, naif, atau kritis. Filsafat pendidikan Freire juga didasarkan pada asumsi bahwa pendidikan itu politik. Dengan bahasa lain, semua aktivitas pendidikan itu memiliki implikasi, kualitas, dan konsekuensi politis, karena semuanya berpengaruh terhadap subjektivitas manusia.
\end{abstract}

Kata kunci: filsafat pendidikan, filsafat manusia, arkeologi kesadaran manusia, politik pendidikan

\section{INTRODUCTION}

The bibliography of Paulo Freire has evolved over the last two decades in line with interest in reinventing his educational philosophy according to different contexts. The literature can bedivided into several categories (Nuryatno, 2008:35-37); first, texts written by Freire himself; second, texts written by him in collaboration with others; third, texts written by scholars exclusively discussing his life and thought; fourth, texts written to compare his thought with other scholars; and fifth, texts written to demonstrate the influence of Freire in certain social con- texts, or in an attempt to apply his theory or methodology in different social contexts.

Freire is "regarded as one of the most (if not the most) important liberation thinkers of the twentieth century" (Peter Robert, 1999:35). His influence had been felt among the Maori's (the indigenous people of New Zealand) communities since the 1970s, when they started to become aware of their multiple oppressions and exploitation and began to question deeply and profoundly the politics of domination. They felt that Freire not only gave them a language 
to articulate their voices, but also provided ideas and strategies to problematize their lives as a colonized people in their own land. However, the relationship between the Maori people and Freire was not a linear one, in the sense that Freire's writings provided a blueprint for liberation. Instead, they came to Freire only after having already conducted resistance and struggle. At this point, Freire's writings strengthened their resolve and gave them direction, affirming and lending validity to their action.

Freire's association with popular education grew out of his activities in promoting critical literacy amongst peasants and workers in Brazil in the early 1960s. He had intention to make them literate and therefore eligible to vote. His pedagogical concept was not based on the conventional framework in which the emphasis is on enabling people to read texts. Freire's literacy mission was broader than this: his aim was to relate the word to the world in order to make the process of learning produce political transformations (Freire and Macedo, 1987: 45)-a subversive view perceived by the military regime as a danger to the status quo.

Freire has also been connected with critical pedagogy, being numbered as one of three sources of this school besides Antonio Gramsci (with his concept of counter-hegemony) and the Frankfurt School's critical theory (Patti Lather, 1998). These three sources provide the main thrust in the continuing development of critical pedagogy, such that even Paula Almann
(1999:17) argues that any cultural action for transformation project must involve the ideas of Freire and Gramsci as its basic ingredients. It is not an exaggeration when Henry Giroux (1998:141) says that "I associate critical pedagogy with the work of Paulo Freire. And I think that anyone who took up the field, in some way, had to begin with him whether they liked him or not." Thus, in any discussion of critical pedagogy it is almost impossible to ignore the legacy of Freire.

\section{KEY ISSUES OF FREIRE'S EDU- CATIONAL PHILOSOPHY}

I will examine three key elements of Freire's thought, namely philosophy of human beings, archeology of consciousness, and the politics of education. These elements are explored in the following pages.

\section{Philosophy of Human Beings}

Freire argues that no educational theory can be separated from the concept of human beings. Freire's philosophy of human beings can be described as Christian-Marxist humanism (John Elias, 1994). As a revolutionary humanist, he demonstrates his profound love for humanity while his pedagogical theory is based on fundamental trust and faith in people. "To be a good educator, you need above all to have faith in human beings" (Freire, 1971, quoted in Ira Shor, 1993:25).

Freire has a very optimistic view of human beings. He believes in the capacity of every human being to think, reflect, and name the world in 
order to create history and culture, no matter how "ignorant" he or she may be. Freire unequivocally rejects the notion of a person as an empty vessel, arguing that every individual has valuable experiential knowledge and opinions through their relations with the world and other human beings. Humans have the capacity to look critically at their world through dialogical encounter with others. $\mathrm{He}$ in fact considered dialogue as an existential necessity. "Dialogue is the encounter of men, mediated by the world, in order to name the world" (Freire, 1971:76).

Freire (1971) explains that humans, as incomplete beings, have an ontological and historical vocation to become more fully human. What he means by 'ontological vocation' is a human being's innate duty to realize his/her full potential as a human. In the process of 'becoming', humans are called upon continually to humanize themselves through naming the world in action-reflection with other humans. By contrast, "dehumanization... is a distortion of the vocation of becoming more fully human" (Freire, 1971:28). Dehumanization must not be perceived as a closed and static reality, but as a limiting situation that can be transformed. Since it is not a given destiny but socially constructed, it is the humanistic and historical task of every individual to challenge and transform it. Thus, humanization is not a gift but a duty that must be pursued through struggle involving a double movement: increasing one's consciousness capacity and changing the context of oppression-both of which are inter-connected dialectically.

Human freedom is a precondition for achieving humanization. Freire believes in the capacity of the oppressed to become "new human beings," who do not imitate their oppressor's personality when they are liberated. Liberation thus aims to produce new human beings who have certain qualifications, such as being just, lenient and democratic as opposed to authoritarian and oppressive.

Humans as subjects are rooted in historical struggle. In his discussion of Paulo Freire, Colin Lankshear (1993: 95) says that for Freire humans "are 'beings of the praxis' who live authentically only when engaged in inquiry and creative transformation of the world." Thus, humans are conscious of their historicity: as historical beings, they are aware of living in a particular time and location constituted by a multiplicity of life's dimensions, such as gender, race, religion, politics, culture, and economics.

Freire (1971:34) argues that the distinctive character of human beings is their capacity to think and engage in the historical world purposively. Reflective capacity enables humans to disassociate themselves from the world and give meaning to it. Thus, human beings can operate in the world through action and reflection for a purpose. They are capable not only of knowing the world, but also of actually knowing that they are knowing it. Humans are in and with the world through critical contact. Since humans 
have the capacity to reflect, they are able to discover the contradictions inherent in reality and how to transform it. They are also able to "name the world" and transform it through their thought-language in order to create history and the future.

John Elias (1994) criticizes Freire for his overly optimistic view on human beings, ignoring the fact that there are similarities and continuities that exist between humans and animals. Human actions are determined and influenced by external as well as unconscious factors. Nor is it not unusual to see humans behave like animals. Human nature has not only a bright side, but also a dark side. People can behave in either a good or an evil manner. The failure to take into account the whole pictures of humanity results in one-sided analysis and "neglects the possibilities that this critical reflection might be combined with self-interest to bring about a more oppressive situation that the previous system of domination" (Elias, 1994:84).

Freire is also criticized for being overly optimistic in his views on liberated persons, as if such people will inevitably behave in a non-oppressive manner and act rationally, or as if when entrusted with power they will use it wisely without exploitation and oppression. The truth, however, often contradicts this view. "The oppressed once freed from oppression at times become the oppressors of others" (Elias, 1994:56). In other words, many liberated individuals when they gain power also use it to oppress others.
For my own part I believe that Freire is not unaware of this fact. He tries to insure against this negative effect by warning the oppressed not to duplicate the oppressor's mentality. Interestingly, Elias also affirms this view by saying that "What Freire rightfully stresses is that this [duplicating the oppressor's mentality] does not necessarily have to happen" (Elias, 1994: 56). Thus, Elias proposes a critique which he later (in the same paragraph) contradicts.

\section{The Archaeology of Consciousness}

The theory of levels of consciousness proposed by Freire is critical to understanding his thought. Freire develops this theory in Education for Critical Consciousness, Pedagogy of the Oppressed and Cultural Action for Freedom. The archaeology of consciousness involves study of the fundamental form of consciousness. Freire argues that "consciousness is constituted in the dialectic of man's objectification of and action upon the world" (1972: 53). He agrees with Marx's view that the social world contributes to shaping the structure of one's consciousness and in turn one's consciousness contributes to shaping the social world. The relationship between the socioeconomic and cultural context and one's structure of consciousness is fundamentally dialectical.

People's consciousness of the world can be observed through the way they perceive their existential reality, i.e., whether they see it naively, superstitiously, or critically. The fundamental question is: Do people distinguish 
that which is natural (what is given) from that which is cultural, i.e., socially constructed? Freire (1985:106) says that "one of the important points in conscientization is to provoke recognition of the world, not as a "given" world, but as a world dynamically "in the making." The ability or inability to distinguish between the two domains determines the stages of consciousness, whether magical, naïve, or critical.

The main characteristic of semiintransitive or magical consciousness is an uncritical or unreflective acceptance of the world. It is called semiintransitive because the individual who possesses it is in no sense a subject who knows objects or things in the world. People with this type of consciousness view their life conditions as inevitable, given, natural, and impervious to change. This fatalistic view is caused by the inability to disassociate from the world. They have a magical attitude that tends to associate life with destiny and attribute historical circumstances to superior powers, i.e., inevitable forces beyond human control.

Poverty and oppression are viewed as an unavoidable fate and a normal condition, rather than as the product of human action and abnormal. Because they take the facts of their socio-cultural situation as a "given," they cannot investigate the socio-economic contradictions within society and problematize their daily life situations. They lack what Freire (1972: 62) calls "structural perception." Their obsession is to meet their elementary needs, and that is why they are so vulnerable to challenges beyond their biological sphere. This form of consciousness is characterized by fear of change, resignation, accommodation and conformity. Freire (1973:44) says: "Magic consciousness is characterized by fatalism, which leads men to fold their arms, resigned to the impossibility of resisting the power of facts."

Freire gives his theory of magic consciousness a Marxist content. It is thus typical of those who are dominated, dependent, and oppressed, of those who live in closed societies with a "culture of silence."In these circumstances, the oppressed see suffering not as the fruit of exploitation, but as the will of God. This lack of historical consciousness combined with a fatalistic viewpoint is no doubt led to cultural submersion and marginality.

The second mode of consciousness is naïve or semi-transitive. It is called transitive because persons at this level begin to become subjects who can dialogue with others, but it is only partly so because they do not yet know reality in a true act of knowing. This type of consciousness is still "quasi-immersed." It is a process of emergence from silence by proposing and interrogating life situations. People at this level begin to understand their socio-historical problems and contradictions, but they tend to oversimplify them and not investigate them thoroughly. They just need simple explanations. This state is open to manipulation by the power elites who use propaganda, slogans, or myths to maintain their oppression. 
Nevertheless, this type of naïve consciousness in transitional societies contributes to paving the way for the masses to become conscious beings who are able to analyze more precisely what constitutes their society.

The highest level of consciousness is critical consciousness, in which people can think as subjects. It is only in this state that true knowing can possibly come into existence. People at this level are able to perceive critically their existential reality via causal relationship analysis, to avoid simple comprehension of reality and text, and to understand the 'deep structure' of reality which people decode, problematize and transform. They also have more self-confidence and openness to other ideas. People at this stage have moved from being pessimistic, fatalistic, passive and apathetic to being optimistic and active.

Freire argues that critical consciousness is brought about via conscientization. In his language, "conscientization represents the development of the awakening of critical awareness" (Freire, 1976:19), wherein the agent must be a subject or a conscious being, not simply one who prise de conscience. It also implies "the critical insertion of the conscientized person into a demythologized reality" (Freire, 1972:75). Thus, in conscientization, political engagement is imperative, because it embraces a critical demystification of an oppressive reality. Conscientization cannot come into existence without denouncing dehumanizing reality and unjust structures and subsequently announcing and proclaiming a non-oppressive reality. "There is no annunciation without denunciation, just as every denunciation generates annunciation" (Freire, 1972:41). The human condition is perceived as socially constructed and politically intervened and, therefore, people have to engage in making history. If human beings can produce social reality, why then can they not change it?

However, it is important to note that critical consciousness cannot be 'imposed' or 'deposited', but must be born through the creative efforts of the people. It also cannot be generated by intellectual effort alone, but needs praxis - the authentic unity of action and reflection.

Freire's theory of consciousness has not been without its critics, although such critics do not provide sufficient reason to dismiss it for analytic purpose. One can argue that Freire tends to simplify the relation between one's consciousness and social participation. Is it true that a person who possesses critical consciousness will automatically participate in societal change? I for one do not think so. Although critical consciousness is a significant factor in determining a person's social participation, it is not the only one. There are other determinant factors that contribute to his/her decision whether to engage in social participation or not, such as the politics of the regime, cultural considerations, the influence of mass media, to name a few.

In defending Freire, Peter Mayo argues that such criticism is out of 
date and results from a failure to analyze his works holistically. He points out that Freire's later writings show "the need for teachers to work in wider contexts outside the school or educational settings and the opportunities provided by social movements" (2004:26). Thus, Mayo argues that Freire's pedagogy does not guarantee that conscientized people will engage in action for social transformation.

However, such a defensive argument requires critical consideration as Freire himself admitted his simplistic analysis of the issue:

My mistake was not that I recognized the fundamental importance of a knowledge of reality in the process of its change, but rather that I did not take these two different momentsthe knowledge of reality and the work of transforming that reality-in their dialectical relationship. It was as if I were saying that to discover reality already meant to transform it (Freire, 1975:15, quoted in Diana Coben, 1998: 75).

Another debate focused on whether Freire's proposal of the types of consciousness justifies the hierarchical modes of consciousness or not. Peter Roberts (2000) presents a fine evaluation of the complex issue of conscientization, particularly in response to the critique of Peter Berger. Berger (1974) contends that Freire's conscientization, as a process of "consciousness raising," is essentially an act of conversion in which certain people impose their cultural beliefs and truths on others in the name of assistance. Freire's proposal seems to justify the hierarchical modes of consciousness in which one may come to be regarded as higher and more useful than others. For Berger (1974:117), "the peasant knows his world far better than any outsider ever can." Each group of people has its own understanding of the world and makes sense of it differently. It is for this reason that any attempt to raise someone's consciousness is impossible, because no one can say that he/she is more conscious than the other. Thus, peasants cannot be regarded as less fully human than those who initiate literacy programs, for instance.

In a response to the above critique, Roberts (2000) argues that Freire's notion of types of consciousness should be located in specific situations, namely, the conditions of people in urban and rural areas of Brazil during and before the early 1960s. Although some features of these modes of consciousness may still persist in today's society, "Freire never intended the categories to be taken as descriptors of ahistorical, universal stages for all individuals in every society to pass through" (Roberts, 2000:144). Roberts suggests that Freire's archeology of consciousness would be more accurately defined as identifying different ways of making sense of the world instead of locating people at a lower level of consciousness than others. He says that:

"He [Freire] is careful not to denigrate the people with whom he was working by declaring them lower beings. 
His point in identifying magical and naïve consciousness is that these forms of thought are shaped by, and, serve the interests of, oppressor class. If there is any group at risk of being "denigrated" by Freire, it is those who deliberately promote a view of the world that reproduces an oppressive social order (Roberts, 2000:145).

To strengthen his argument, Roberts presents Kevin Harris's (1979:174) strong defense of Freire. Harris argues that consciousness-raising is necessary and desirable in situations where people do not understand their existential reality. In contrast to Berger, for Harris, any individual can achieve the stage of critical consciousness, regardless of their social status, either empowered/educated or exploited/deprived. Consciousness-raising does not mean imposing one's view on another; rather, it consists in encouraging people to examine their world critically.

I agree with Harris's position. I suspect that Berger's criticism is driven by a view of the neutrality of literacy or pedagogical practice. This position may lead someone to judge educational intervention as equal to imposition. I would like to argue that, although we must respect multi-cultural perspectives and beliefs, this does not necessarily mean that educational practice should be neutral and without any value. Freire's position is clear: "the neutrality of education is one of the fundamental connotations of the naïve vision of education" (1987:41). Pedagogy is never neutral because it is an act of politics and intervention, but this does not mean that it is an imposition, because the way it is delivered is through dialogue, not coercion. Furthermore, Freire argues that critical consciousness cannot be 'imposed' or 'deposited', but must be born through the creative effort of individuals.

\section{Politics of Education}

Antonio Gramsci views politics as educative, in the sense that he gives his political activities educational content (Diana Coben, 1998). Politics is not merely regarded as the art of gaining power: it has an educational value. This position has situated Gramsci as one of the sources of adult education. Likewise, Ernesto "Che" Guevara gave his revolutionary action educational content. He once said: "If you want an education, join the revolution" (quoted in Jim Walker, 1981: 120). Freire starts from a different point of departure compared to these figures. Instead of giving politics or revolution educational content, he gives education political content. For him, educators should be aware of the political nature of their practice. "It is not enough to say that education is a political act, just as it is not enough to say that political acts are also educative. It is necessary to truly assume the political nature of education" (Freire, 1998:46).

Why does Freire give education political content? This is because his educational philosophy is based on praxis philosophy, an authentic and dialectical relation between reflection and action. At this point, Freire adds 
new meaning to Marx's famous eleventh thesis on Feuerbach: "The philosophers have only interpreted the world in various ways; the point, however, is to change it" (Cornell West, 1993:xiii).

Pedagogy of the Oppressed is full of political nuance, manifested in the vocabulary of oppression, dehumanization, objecthood, culture of silence, liberation, emancipation, conscientization, subjecthood, humanization, etc. These terms are a clear indication of Freire's belief in the power and potency of education to bring about social change through human agency. The ideal construction of education is one that is ethical and utopian, one that can enlarge the democratic public sphere and produce a just social structure in which humanity is protected and the human condition improved.

Freire proposes education as a "language of critique" (Giroux, 1992: 18) by relating education to power and politics because these three domains are intertwined. Education arguably cannot be separated from the wider social context in which it exists, for it is constituted by a multiplicity of dimensions in a given social formation. Instead of adapting to socio-political formation, education has taken on the role of producing and creating public life. The real question actually is not whether education can create public life, but "What kind of public does it create?" (Neil Postman, 1995: 18).

However, Freire's politics of liberation is not merely based on a "language of critique" but also a "language of hope." Hope is neither static nor solely emotional, but a motor force and an "ontological need"" (Freire, 1994:8), which is imperative in liberatory education.

Freire's notion of shifting the focus of learning from teacher to student unquestionably alters the power relationship, not only in the classroom but in the social sphere as well. His statement that "education is politics" (Freire, 1987:46) means that all educational activities are political in nature and have political qualities and consequences. The ways the teacher teaches, the knowledge preference that will be delivered, and the mode of relation that will be built, are all political, because they all contribute to either liberating or domesticating the student.

Teachers should be consistent with their political choice and values. It is absurd for teachers to proclaim and teach democracy and justice while at the same time repressing individual voices in the class. It is hard to accept a teacher who advocates democracy, equality, and egalitarian principles while maintaining an authoritarian relationship with his her pupils. Consistency between speaking and acting is important to be maintained within the educator.

Education as a political act also means that learning in the classroom is not merely a matter of knowledge acquisition and transmission; rather, it is a process of developing critical subjectivities in which the existing knowledge and power are continuously questioned. What is insisted 
upon in the process of learning is, thus, not how to have and accumulate knowledge, but how to understand, critique, produce and use knowledge as a means of transforming reality (Almann, 1999:17). Only in this perspective does the process of learning produce political implications.

Freire argues that not only is methodology important to the process of learning, but so is the content, because it plays a significant role in the formation of subjectivities, i.e., the way students understand the world. At this point, it is important to look at how Henry A. Giroux (1983:176-204) and Peter McLaren (1998:174-175) develop what is called "emancipatory knowledge," a notion that is inspired by Jurgen Habermas but which has a strong connection with Freire's thought.

Following Habermas, they divide knowledge into three types: technical, practical and emancipatory. The characteristics of technical knowledge are control, certainty, objectivity and value-free. The implication for educational theory is that it should operate in the interests of a lawlike mode of thought and separate knowledge from its process of constitution. A process of learning based on technical knowledge leads to a dialectical contradiction between teachers who serve as transmitters of knowledge and students who turn out to be passive consumers, a position that makes it possible for the former to sort, regulate, and control the latter.

The second type is practical knowledge, which provides the hermeneu- tical tool of analysis necessary to interpret the nature of reality. It helps students to analyze the categories and assumptions that constitute reality and how they contribute to one's understanding of the world. The constitution of reality is mediated by language whereby human beings constantly produce and reproduce meanings through their interpretation of the world. The implication of this model for education is that knowledge is not delivered via imposition but rather is mediated through mutual dialogue among learners. Students are encouraged to explore and articulate their own values and to understand and evaluate them in terms of everyday life experiences. However, it inevitably fails to develop the type of analysis that can enable students to identify the relationship between knowledge and power, particularly how the dominant power and ideology produce a set of meanings, understandings and practices that support and sustain their structural domination, while at the same time preventing the emergence of a critical community.

The final type is emancipatory knowledge, which orients students to comprehend social reality based on dialectical relations of power, arguing that reality is constituted by competing paradigms, each of which brings its own agenda, interest, value and ideology. The learning process, therefore, aims to critique knowledge and demystify the ideological interests behind the construction of social reality, and then take action to create a form 
of reality that is based on democratic and just principles. At this point, emancipatory knowledge attempts to transcend the mechanistic view of technical knowledge and to move beyond the category of understanding (insisted upon by practical interests) in order to arrive at transformation. Emancipatory knowledge encourages and strives for self-reflection. Presenting emancipatory knowledge in the classroom has the effect of transforming students into subjects-independent and liberated beings who have found their voices.

Emancipatory knowledge is constituted on the basis of critique and action, meaning that it always engagees, as part of the historical process, in critiquing social reality and taking action to improve it. The basis for judging knowledge then is not whether it is "right" or "wrong," but whether it is liberative or oppressive. If so, the process of learning that serves to disseminate this mode of thinking should be designed so as to promote the critical awareness and personal freedom necessary for the individual's self-formation. This is the type of knowledge that can truly empower students.

\section{LIMITATIONS OF FREIRE'S THOUGHT}

Freire's thought should not be accepted blindly or without critique. Freire himself urges his readers not to accept any ideas coming from another part of the world at face value, since these are always socially constructed and historically situated through the medium of language. His advice is to re-examine their suitability before transplanting them into another social context to avoid the imposition of one culture over another. There are some critics that can be addressed to Freire's educational thought.

\section{Critique \# 1: Two Simplistic Catego- ries}

Freire has over polarized view of reality, which for him is always divided into two categories, such as banking versus liberatory pedagogy, oppressor-oppressed, dominator-dominated, subject-object, and domesticcator-domesticated. This extreme polarization is a clear indication that he prefers one side and rejects the other. His magnum opus is, unsurprisingly, entitled Pedagogy of the Oppressed. Freire makes a clear choice in taking the side of the underclass.

Criticism of this approach is frequently offered, particularly deals with the tendency to see the world in terms of black-white or right-wrong categories, when in fact reality is far too complex to reduce it to such categories alone. Presenting positions in diametrical or polar opposition contributes to the production of simplistic analysis, because the world is actually not as simple as this. This way of thinking disregards the possibility that the same person in different situations can be the subject or the oppressor, and in others the object or the oppressed.

Freire's tendency to see society in terms of two extreme perspectives has also been criticized for lack of con- 
sistency. He seems to believe that the world of oppression cannot be seen except from the structural perspective. The problem with this view is that: What if a people's story does not correspond to the theory of oppresssion? What if a people's suffering is not caused by structural oppression? It can be argued that structural oppression is only one of many sources of the suffering of people, but not the only one. There are other sources, such as natural disasters, ethnic and religious conflict, illness, corrupt bureaucracy, poverty, sexual violence, and the global market. Not all of these are caused by domination and oppression. Therefore, it is questionable whether his method can be applied to a group of learners whose main problem is not structural oppression, but something else. To be consistent with his theory that the existential reality of students should serve as the entry point of the learning process, Freire's model cannot possibly be applied in every situation.

From the above perspective, the oppressor-oppressed way of thinking is not always accurate for interpreting the meaning of social life. Since dividing the world into two categories is inadequate for an understanding of the complexities of life, it is necessary to extend the categories to include the concepts of class struggle, patriarchy and feminism, or difability, to name only a few. These categories can help people question and criticize a part of their existential reality, but not the whole of it because there is no single approach that can explain the whole phenomenon.

\section{Critique \# 2: Simplistic Analysis}

Freire argues that there is an intimate relation between knowing and action, in the sense that our understanding of reality leads to action. He says, "It so happens every understanding, sooner or later an action corresponds. Once man perceives a challenge, understands it, and recognizes the possibilities of response, he acts" (Freire, 1973:44). At this point, Freire views an automatic relation between critical understanding, critical consciousness, and critical action. But is this really the case?

Freire's view that knowing automatically leads to action is subject to criticism. Assuming that critical consciousness is always connected significantly to social action is a facile analysis, because the case is not as simple as this since each element has its own dynamic: they are not always interconnected. There must be a kind of connecting factor between critical consciousness and cultural action without which the former finds it difficult to produce the latter.

This kind of criticism is denied by Peter Mayo (2004:60), arguing that "Freire's pedagogy does not guarantee that people will engage in action for social transformation once they become conscientized and begin to critically read the world."However, Mayo's defense is weak to justify because Freire himself admitted his failure to not differentiate between two moments, i.e., a moment of perceiving 
reality critically and moment of transforming that reality. This failure brings about the conclusion that "to discover reality meant to transform it" (Freire, 1975:15, as quoted in Diana Coben, 1998:75).

\section{Critique \# 3: Inconsistency between Theory and Practice}

Freire elsewhere mentions the importance of dialogue to the learning process because it is the fulfillment of one's ontological vocation. What is dialogue? Freire (1971:76) explains that "dialogue is the encounter between men, mediated by the world, in order to name the world." $\mathrm{He}$ also says that, "Only dialogue, which requires critical thinking, is also capable of generating critical thinking. Without dialogue, there is no communication, and without communication there can be no true education" (1971: 81). Thus, it is impossible to have democratic learning in the absence of dialogue. Through dialogue, the dichotomy between the teacher, who is supposed to know everything, and the student, who is supposed to know nothing, no longer exists: both become learners who teach and are taught. As a result, "arguments based on 'authority' are no longer valid" (Freire, 1971:67).

This notion does not necessarily reduce the function of teachers to that of mere 'facilitators,' a position that Freire explicitly repudiated because he saw their task as one of contributing, together with students, to the production of knowledge. Freire pointed out that "Teachers maintain a certain level of authority through the depth and breadth of knowledge of the subject matter that they teach" (Freire, 1987, quoted in Allman, 1998:12). However, he also insisted that the meaning of authority is not equivalent to authoritarianism, because the latter intrinsically contradicts the spirit of democracy that lies at the heart of Freire's struggle.

The insistence on dialogue in the learning process aims at avoiding narrative teaching, which in turn depends on subject-object relationship. The content of learning in narrative teaching is lifeless, because it is delivered in the form of one-way communication. As a result, there is no knowledgeproduction, because knowledge is regarded as a static entity, "a corps of information-a dead body of knowledge-not a living connection to their reality" (Ira Shor and Paulo Freire, 1987:4). Teaching then is considered as technical matter per se: it is not intended to raise consciousness within learners. Narrative teaching is typical of banking education.

However, in his later book, $A$ Pedagogy for Liberation, Freire (1987:40) clarifies that "by criticizing banking education we have to recognize that not all kinds of lecturing is banking education." He argues that lecturing can be used as oral codification that will later on be decoded by students and teacher.

At this point, Mansour Fakih (2003) accuses Freire of being inconsistent with regard to dialogical method and knowledge production in the learning process. In other words, 
he proposes and insists on a certain methodology, but does not follow through in practice. When Fakih met Freire in 1989 and took a class with him, he formed a very different impression. His teaching method was hardly as provocative or powerful as he had expected: it was just common adult education. Rather than encountering the Freirean technique in class, he met with an anti-Freirean approach, because Freire himself employed lecture and narration in the learning process. As a result, he dominated the class, contradicting what he had said in his Pedagogy of the Oppressed, where he insists on dialogue. At this point, there was no gnosiological cycle, i.e., the dialectical relation between the moment of producing new knowledge and the moment of knowing the new knowledge, as insisted on by Freire. By relying on lecturing as his method of teaching, Freire had reduced the importance of dialogue. Content and method are equally important in the learning process, because no matter how good the content, when it is delivered in a non-dialogical way it can be metamorphosed into dogma.

Thus, Fakih had different impression after meeting Freire. Before, Fakih felt that his ideas were truly provocative, revolutionary and powerful. He experienced a great desire to develop Freire's ideas in practice, seeing in them the seeds of leftist struggle. However, this impression suddenly disappeared when he found that Freire's teaching method betray- ed his own principle by using monologue as a way of communication.

\section{CONCLUSION}

Paulo Freire is one of the most influential thinkers of education in the twentieth century. His ideas have been implemented in various places and contexts. Freire's philosophy of education can be divided into three parts: philosophy of human beings, the archeology of consciousness, and education is politics. Freire's philosophy of human beings can be described as Christian-Marxist humanism. He demonstrates his profound love for humanity while his pedagogical theory is based on fundamental trust and faith in people. Freire divides three types of people's consciousness: magical, naïve, and critical consciousness. Process of learning is oriented to develop people's capacity to see the world in critical way so that they will be able to live in and with the world. In terms of the relation between education and politics, Freire argues that education is not valuefree, but it is political. He gives education political content. For him, educators should be aware of the political nature of their practice. The reason why Freire emphasizes on politics of education is because his educational philosophy is based on praxis philosophy, an authentic and dialectical relation between reflection and action.

\section{ACKNOWLEDGEMENTS}

I would like to thank to Prof. Steven Jordan, who helps me to make this article more insightful. 
REFERENCES

Allmann, Paula. 1998. Revolutionary Sosial Transformation: Democratic Hopes, Political Possibilities and Critical Education. Westport, CT and London: Bergin \& Garvey.

Berger, Peter. 1974. Pyramids of Sacrifice: Political Ethics and Social Change. New York: Basic Book.

Carnoy, Martin. 1998. "Interview with Martin Carnoy". (Carlos Alberto Torres). Education, Power, and Personal Biography: Dialogues with Critical Educators. New York dan London: Routledge.

Coben, Diana. 1998. Radical Heroes: Gramsci, Freire, and the Politics of Education. New York: Garland Pub.

Elias, John. 1994. Paulo Freire: Pedagogous of Liberation. Malabar, Fla.: Krieger Pub. Co.

Fakih, Mansour. 2003. Personal interview, 15 May 2003.

Freire, Paulo. 1971. Pedagogy of the Oppressed. New York: Herder and Herder. . 1972. Cultural Action for Freedom. Harmondsworth: Penguin. - 1973. Education for Critical Consciousness. New York: Seabury Press.
. 1985. The Politics of Education: Culture, Power and Liberation. Massachusetts: Bergin \& Garvey.

- 1998. Politics and Education. University of California, LA: UCLA Latin American Center Publications.

Freire, Paulo dan Donaldo P. Macedo. 1987. Literacy: Reading the Word and the World. South Hadley, Mass.: Bergin \& Garvey Publishers.

Freire, Paulo dan Ana Maria Araujo. 1994. Pedagogy of Hope: Reliving Pedagogy of the Oppressed. New York: Continuum.

Gadotti, Moacir dan Carlos Alberto Torres. 1997. "Paulo Freire: A Homage". Taboo: The Journal of Culture and Education, vol. II, Fall, hal. 96-101.

Giroux, Henry A. 1983. Theory and Resistance in Education: A Pedagogy for the Opposition. New York: Bergin \& Harvey Publishers, Inc.

Giroux, Henry A. 1993. Border Crossing: A Cultural Workers and the Politics of Education. New York: Routledge.

Giroux, Henry A. 1998. Pedagogy and the Politics of Hope: Theory, Cul- 
ture, and Schooling. Boulder, Colo.: Westview Press.

Harris, Kevin. 1979. Education and Knowledge. London: Routledge and Kegan Paul.

Lankshear, Colin. 1993. "Functional Literacy from a Point of View". Dalam Peter McLaren dan Peter Leonard (Ed.), Paulo Freire: A Critical Encounter. London dan New York: Routledge.

Lather, Patti. 1996. "Critical Pedagogy and its Complicities: A Praxis of Stuck Places". Educational Theory, 48: 487-497.

Mayo, Peter. 1998. Gramsci, Freire, and Adult Education: Possibilities for Transformative Action. London \& New York: Zed Books.

Mayo, Peter. 2004. Liberating Praxis: Paulo Freire's Legacy for Radical Education and Politics. Westport, CT: Preager.

McLaren, Peter and Henry A. Giroux. 1997. Writing from the Margins: Geographies of Identity, Pedagogy and Power. In Peter McLaren (Ed.) Revolutionary Multi-Culturalism: Pedagogies of Dissent for the New Millennium. Colorado: Westview Press.

Nuryatno, M. Agus. 2008. Mazhab Pendidikan Kritis. Yogyakarta: Resistbook.
Roberts, Peter. 2000. Education, Literacy, and Humanization: Exploring the Work of Paulo Freire. Westport, CT: Bergin \& Garvey.

Shor, Ira and Paulo Freire.1987. A pedagogy for liberation: dialogues on transforming education. South Hadley, Mass.: Bergin \& Garvey Publishers.

Taylor, Paul V. 1993. The Texts of Paulo Freire. Philadelphia: Open University Press.

Walker, Jim. 1981. “The End of Dialogue: Paulo Freire on Politics and Education". In Robert MacKie (editor), Literacy and Revolution: the Pedagogy of Paulo Freire. New York: Continuum.

West, Cornell. 1993. "Preface". Dalam Peter McLaren and Peter Leonard (editor), Paulo Freire: A Critical Encounter. London and New York: Routledge. 